\title{
Consequence of Smoke from Crude Oil Contaminated Firewood on Female Reproductive Hormones and Oxidative Stress Biomarkers of Wistar Rats
}

\author{
*DIKE, CO; IFEANACHO, MO; BELONWU, DC
}

\author{
Department of Biochemistry, Faculty of Science, University of Port Harcourt, Port Harcourt Nigeria \\ *Corresponding author Email: dico.dike@yahoo.com; mifeanachoyahoo.com; chukabells2003gmail.co
}

\begin{abstract}
The study evaluated the effect of smoke from crude oil contaminated firewood on selected female reproductive hormones and oxidative stress biomarkers of wistar rats. The smoke exposure lasted for 28 days. Carbon monoxide (CO), Oxides of Nitrogen $\left(\mathrm{NO}_{\mathrm{x}}\right.$ ), Oxides of Sulphur $\left(\mathrm{SO}_{\mathrm{x}}\right)$, Hydrogen sulphide $\left(\mathrm{H}_{2} \mathrm{~S}\right)$, Methane $\left(\mathrm{CH}_{4}\right.$, Volatile Organic Compound (VOC), Ammonia $\left(\mathrm{NH}_{3}\right)$ and Particulate Matter (PM) $(1,2.5,10)$ were determined in the smoke generated from the burning of firewood harvested from crude oil polluted site. Oxidative stress biomarker (Catalase (CAT), Malondialdehyde (MDA), Superoxide dismutase (SOD) and glutathione (GSH) and female reproductive hormone (FSH, LH and estrogen) were evaluated in the wistar rats exposed to smoke generated from this firewood. The air profile values of the polluted firewood smoke was $\mathrm{CO}(112.3 \mathrm{ppm}), \mathrm{SO}_{2}(0.61 \mathrm{ppm})$, VOC (3.5ppm), $\mathrm{NH}_{3}(2.63 \mathrm{ppm}), \mathrm{PM}_{1}$ $(0.11 \mathrm{ppm}), \mathrm{PM}_{2.5}(0.16 \mathrm{ppm}), \mathrm{PM}_{10}(0.27 \mathrm{ppm})$. The estrogen level in all the groups were significantly reduced when compared to the control except for group 2 which has no significant change ( $\mathrm{p} \geq 0.05)$. The oxidative stress markers SOD and CAT were significantly increased $(p \leq 0.05)$ in groups $3,4,6$ and 7 . MDA were significantly increase $(p \leq 0.05)$ in groups 6 and 7. These results reveal that smoke of firewood from an oil impacted environment have the potential to elici toxic effects on selected reproductive hormones and oxidative stress in wistar rats.
\end{abstract}

\section{DOI: https://dx.doi.org/10.4314/jasem.v22i6.2}

Copyright: Copyright $(02018$ Dike et al. This is an open access article distributed under the Creative Commons Attribution License (CCL), which permits unrestricted use, distribution, and reproduction in any medium, provided the original work is properly cited.

Dates: Received: 25 March 2018; Revised: 03 May: 2018; Accepted: 24 May2018

Keyword: Air pollution, Smoke, Reproductive hormone, Oxidative stress.

Wood burning is a major contributor to air pollution and this is a problem because most people believe that since wood smoke is a natural substance it has to be devoid of harmful substance but it has been established that wood smoke from firewood stove, agricultural fires etc emit considerable quantities of known health harmful pollutants, including several carcinogenic compounds like $\mathrm{CO}, \mathrm{NO}_{2}$, benzene and also some endocrine disrupting chemicals (EDCs) like, dioxin, PAHs, and particulate matter (Villeneuve et al., 2012). These EDCs are capable of antagonizing the action of hormones (Crisp et al., 1998). Hormones play important roles in human system. For example fertilityin both male and female are majorly controlled by hormones and anything that disrupts these hormones can lead to infertility which is now becoming a global problem. Report from World Health Organization (WHO) state that approximately 8 to $10 \%$ of couples globally are faced with some kind of infertility problem. This is to say that 50 to 80 million people are facing the problem of getting a complete family. In the USA, about 5 million people have infertility problems, while in Europe the incidence is projected around $14 \%$. In West African infertility rate is around 50\% (Gnoth et al., (2005), Benagiano and Brosens, (2006). Among the causes of infertility studied female infertility contributesabout 40 to $50 \%$. Combined female and male infertility factor accounts for 20\%-30\%. Unexplained causes accounts for $15 \%$ of infertility case (DeCherneyet al., 2003). An infertility case is termed unexplained when the normal infertility examination have all read normal. Information from National Survey for Family Growth, shows that the number of women with impaired reproductive state has increased by $35 \%$ from 1982 to 1997 (DeCherneyet al., 2003). According to Caserta et al., 2008 and fosteret al., 2008 environmental and occupational factors are among the variables that may cause infertility in females. In Nigeria most people have resorted to the use of firewood as their major source of energy for cooking as a result of the high cost of kerosene and other cooking fuels. This they do without knowing the influence the practiceshas on their health. Oxidative stress, ROS and antioxidants remain in balance in normal physiological conditions. When the balance is disrupted as a result of elevated level of ROS or decreased level of natural antioxidant oxidative stress is said to have occurred. Unrelenting and elevated production of ROS is more often the cause of Oxidative Stress and this can overwhelm the antioxidant reserves (Linnaneet al., 2007). Age-related

*Corresponding author Email:dico.dike@yahoo.com; mifeanachoyahoo.com; chukabells2003gmail.co 
decline in fertility has been attributed to free radical damage (De-Bruin et al., 2002). ROS are key messengers in maintaining physiological functions in the female reproductive tract. However excessive and unrelenting ROS generation causes various pathologies in the female reproductive tract. The aim of this study is to investigate the effect of air polluted with smoke from crude oil polluted wood on selected female hormones and oxidative stress biomarkers.

\section{MATERIALS AND METHODOLOGY}

Popular firewood among the oil rich region of Nigeria (Rhizophoraracemosa) was collected from two different locations. The polluted Rhizophoraracemosa stem was collected from an abandoned artisan refinery site in Sangama in Bonny local government area of
Rivers state while the non-polluted Rhizophoraracemosa was collected from Nwaorie River in Imo State.

Animals: Female wistar rats (weighing 100-150g at the start of the study) were obtained from the Department of Veterinary Medicine, University of Nigeria Nsukka, Enugu State. Studies were conducted in compliance with applicable laws and regulations for handling experimental animals. The animals were weighed and sorted into seven groups of five animals each, so that the average weights were approximately equal. The animals were housed in individual cages and acclimatized for 1 week on growers mesh and water fed ad libitum.

\begin{tabular}{lll} 
& & Table 1.Experimental Design \\
\hline Group Number & I.D & Treatment \\
\hline 1 & Normal control & Exposed to ambient air \\
2 & Test Control I & Exposed to smoke from non crude oil polluted firewood for 10 minutes \\
3 & Test Control II & Exposed to smoke from non crude oil polluted firewood for 30 minutes \\
4 & Test Control III & Exposed to smoke from non crude oil polluted firewood for 60 minutes \\
5 & Treatment I & Exposed to smoke from crude oil polluted firewood for 10 minutes \\
6 & Treatment II & Exposed to smoke from crude oil polluted firewood for 30 minutes \\
7 & Treatment III & Exposed to smoke from crude oil polluted firewood for 30 minutes \\
\hline
\end{tabular}

Air quality sampling and testing:During the smoke exposure air quality was monitored. The meteorological parameters monitored included; carbon monoxide, nitrogen IV oxide, sulphur IV oxide, hydrogen sulphide, volatile organic compounds, ammonia, methane and particulate matter (1, 2.5, and 10 micron). This was done using an Industrial Scientific Corporation IBRID MX6 MultiGas monitor. Measurement was done by placing the sensor in the cages and reading was recorded at stability.

Determination of Oxidative Stress Biomarkers:Catalase activity assay was assayed according to Clairborne (1995) with slight modification.

Superoxide Dismutase Activity Assay (SOD): The determination of SOD was based on the ability of SOD to inhibit the autoxidation of epinephrine at $\mathrm{pH} 10.2$.

Estimation of reduced Glutathione (GSH) level:The method of Sadlak and Lindsay (1968) was followed in estimating the level of reduced glutathione. The reduced form of glutathione comprises most instances the bulk of cellular non-protein sulfhydryl group.

Determination of Malondialdehyde (MDA): Lipid peroxidation was determined by measuring the formation of thiobarbituric acid reactive substance
(TBARS) according to the method of Ohkawaet al., (1979). Under acidic condition, MDA produced from the peroxidation of fatty acid membranes and food products react with the chromoogenic reagent, 2thiobarbituric acid (TBA), to yield a pink coloured complex with maximum absorbance at $532 \mathrm{~nm}$.

Determination of Follicle Stimulating Hormone $(F S H)$ :FSH level in serum was determined according to a commercial test kit (Accu-Bind ELISA). In this method standards of FSH and test sample were made to react with the antigen coated in a microplate well. Biotinylated monoclonal and enzyme labeled antibodies were added. This formed a sandwich complex between the antigen, antibody and enzyme. The excess of the antibody-enzyme complex that did not bind to any antigen after the incubation period were washed off. The activity of the enzyme-antibodyantigen complex present in the surface of the well was then quantified by reaction with a suitable substrate to produce colour. With the help to known FSH concentration a dose response curve was plotted from which an unknown specimen's activity can be correlated with follicle stimulating hormone.

Determination of luteinzing hormone (LH):The quantitative determination of luteinzing hormone concentration in serum was done using the method according to a commercial test kit (Accu-Bind 
ELISA). In this method standards of LH and test sample were made to react with the antigen coated a microplate well. Biotinylated monoclonal and enzyme labelled antibodies were added. This formed a sandwich complex between the antigen, antibody and enzyme. The excess of the antibody-enzyme complex that did not bind to any antigen after the incubation period was washed off. The activity of the enzymeantibody-antigen complex present in the surface of the well was then quantified by reaction with a suitable substrate to produce colour. With the help to known FSH concentration a dose response curve was plotted from which an unknown specimen's activity can be correlated with luteinzing hormone. To determine LH, microplate wells corresponding to the serum reference and test sample was arranged in the microplate. Exactly $50 \mu 1$ to appropriate serum reference and test sample were added to the microplate wells and $100 \mu 1$ of FSH-enzyme reagent solution was then added in the same order the samples was added. This is to minimize reaction time difference between wells. The mixture was allowed to incubate for 60minutes after gentle swirl to mix the solution. After incubation the content of the microplate was discarded and $350 \mu 1$ of wash buffer was used to wash the wells three times. Then $100 \mu 1$ of working substrate solution was added to all well and allowed to incubate for 15 minutes. At the end of incubation $50 \mu 1$ of stop solution was added to each well and gently mix for 15-20 seconds. After which the absorbance in each well was read at $450 \mathrm{~nm}$ in a microplate reader.

Determination of estrogen in serum:The quantitative determination of estrogen concentration in serum was done using the method according to a commercial test kit (Accu-Bind ELISA). This method used a delayed competitive enzyme immunoassay technique.

Statistical Analysis: All data were subjected to statistical analysis. Values were reported as mean \pm standard error mean (SEM), while one way ANOVA was used to test for significance using statistical package for social sciences (SPSS). The results were considered significant at values of less than 0.5 , which is $95 \%$ confidence level $(\mathrm{p} \leq 0.05)$.

\section{RESULTS AND DISCUSSION}

The result of the smoke components for both the test wood and that of the control are shown in table 1. The smoke components measured were Sulfur IV Oxides $\left(\mathrm{SO}_{2}\right)$, Nitric Oxide $\left(\mathrm{NO}_{2}\right)$, Hydrogen Sulfide $\left(\mathrm{H}_{2} \mathrm{~S}\right)$, Carbone Monoxide (CO), Methane $\left(\mathrm{CH}_{4}\right)$, Ammonia $\left(\mathrm{NH}_{3}\right)$, Volatile Organic Compound (VOC), Particulate matter (PM 1, 2.5, 10). Smoke component, $\mathrm{NO}_{2}, \mathrm{SO}_{2}, \mathrm{CH}_{4}$ and $\mathrm{H}_{2} \mathrm{~S}$ were all below detectable limit in in the control wood. In the test wood, $\mathrm{NO}_{2}, \mathrm{CH}_{4}$ and
$\mathrm{H}_{2} \mathrm{~S}$ were below detectable limit. When the smoke components generated from both wood was compared to the ambient air, a high significant value at $(\mathrm{p}<0.05)$ were seen with the pollutants $\mathrm{CO}, \mathrm{VOC}, \mathrm{PM}_{1}$ and $\mathrm{PM}_{10}$ also the values of pollutant in the test wood was significantly higher at $(\mathrm{p}<0.05)$ to those obtained from the control wood. These results were similar to those obtained by the Australian Air toxic National Environment Protection Measure (NEPM) which measured some air pollutant produced as a result of indoor wood burning. These pollutants measured have been seen to pose a lot of health challenge which includes cancer and respiratory diseases. Particulate matter in particular due to its small size can overcome the defence system of lungs and has the ability to case aggravation of asthma. This result shows that people exposed to smoke emanating from polluted wood stand a higher chance of developing health challenges associated with exposure to polluted air.

The variations in the female reproductive hormones in female wistar rats exposed to smoke generated from the test wood and control wood at varying time showed a significant decrease $(\mathrm{p}<0.05)$ in the estrogen level of the animals exposed for 30 minutes and 60 minutes smoke generated from wood collected from non-crude oil polluted environment and also in those exposed for 10 minutes, 30 minutes and 60 minutes smoke generated from crude oil polluted wood when compared to the control. The reduction was observed to increase as exposure time increases and as level of pollutant increases. There was also a decrease in level of FSH and LH although not significant $(\mathrm{p}<0.05)$ when compared to the control. It was observed also that increments in the duration of exposure and levels of pollutants also lead to a substantial reduction in FSH and LH levels. Similar result was recorded by Mohallemet al., (2005) that exposed female mice to some air pollutants. Estrogen plays a lot of role in the reproductive system of a female. It controls the secondary sex characters in female and also help regulate and maintain proper menstrual cycles. Its reduction to a certain level can greatly affect the fertility of a woman at premenopausal stage of life.

Table 1: Major Air Pollutants measured in Ambient Air, Test Wood and Control Wood Smoke.

\begin{tabular}{lccc}
\hline & $\begin{array}{c}\text { Ambient } \\
\text { air(ppm) }\end{array}$ & $\begin{array}{l}\text { Smoke of } \\
\text { Control wood } \\
(\mathrm{ppm})\end{array}$ & $\begin{array}{c}\text { Smoke of Test } \\
\text { wood (ppm) }\end{array}$ \\
\hline $\mathrm{NO}_{2}$ & $0.0 \pm 0.00$ & $0.0 \pm 0.00$ & $0.0 \pm 0.00$ \\
$\mathrm{CO}$ & $0.00 \pm 0.00^{\mathrm{a}}$ & $48.67 \pm 2.6^{\mathrm{b}, \mathrm{c}}$ & $112.3 \pm 8.7^{\mathrm{b}, \mathrm{d}}$ \\
$\mathrm{VOC}$ & $0.9 \pm 0.20^{\mathrm{a}}$ & $2.2 \pm 0.12^{\mathrm{b}, \mathrm{c}}$ & $3.5 \pm 0.23^{\mathrm{b}, \mathrm{d}}$ \\
$\mathrm{CH}_{4}$ & $0.0 \pm 0.00$ & $0.0 \pm 0.00$ & $0.0 \pm 0.00$ \\
$\mathrm{NH}_{3}$ & $0.57 \pm 0.22^{\mathrm{a}}$ & $0.73 \pm 0.15^{\mathrm{a}, \mathrm{c}}$ & $2.63 \pm 0.35^{\mathrm{b}, \mathrm{d}}$ \\
$\mathrm{SO}_{2}$ & $0.00 \pm 0.00^{\mathrm{a}}$ & $0.00 \pm 0.00^{\mathrm{a}, \mathrm{c}}$ & $0.61 \pm 0.04^{\mathrm{b}, \mathrm{d}}$ \\
\hline
\end{tabular}




\begin{tabular}{lccc}
\hline $\mathrm{H}_{2} \mathrm{~S}$ & $0.0 \pm 0.00$ & $0.0 \pm 0.00$ & $0.0 \pm 0.00$ \\
$\mathrm{PM}_{1}$ & $0.00 \pm 0.00^{\mathrm{a}}$ & $0.1 \pm 0.00^{\mathrm{b}, \mathrm{c}}$ & $0.11 \pm 0.01^{\mathrm{b}, \mathrm{c}}$ \\
$\mathrm{PM}_{2.5}$ & $0.00 \pm 0.00^{\mathrm{a}}$ & $0.12 \pm 0.00^{\mathrm{a}, \mathrm{c}}$ & $0.16 \pm 0.02^{\mathrm{a}, \mathrm{d}}$ \\
$\mathrm{PM}_{10}$ & $0.00 \pm 0.00^{\mathrm{a}}$ & $0.12 \pm 0.00^{\mathrm{b}, \mathrm{c}}$ & $0.27 \pm 0.00^{\mathrm{b}, \mathrm{d}}$ \\
\hline
\end{tabular}

Note: Values are means \pm SEM (SEM). Values with the different superscript are statistical significant at $(p<0.05)$. Superscript $(a, b)$ compared the ambient air with all the smoke. Superscript $(c, d)$ compared the smoke produced from test wood and control wood

Female Reproductive Hormone Results

Table 2: The serum level of selected female reproductive hormone in female wistar rats exposed to smoke generated from Test wood and control wood

\begin{tabular}{llcc}
\hline & $\begin{array}{l}\text { ESTROGEN } \\
(\mathrm{mmole} / \mathrm{l})\end{array}$ & $\begin{array}{l}\text { LH } \\
(\mathrm{mmole} / \mathrm{l})\end{array}$ & $\begin{array}{l}\text { FSH } \\
(\mathrm{mmole} / \mathrm{l})\end{array}$ \\
\hline CONTROL & $104.56 \pm 3.10^{\mathrm{a}}$ & $7.76 \pm 0.76^{\mathrm{a}}$ & $4.54 \pm 0.28^{\mathrm{a}}$ \\
10 NP WOOD & $88.13 \pm 8.79^{\mathrm{a}, \mathrm{c}}$ & $7.07 \pm 0.46^{\mathrm{a}, \mathrm{c}}$ & $4.72 \pm 1.19^{\mathrm{a}, \mathrm{c}}$ \\
30 NP WOOD & $56.72 \pm 3.25^{\mathrm{b}, \mathrm{e}}$ & $6.98 \pm 1.04^{\mathrm{a}, \mathrm{e}}$ & $4.85 \pm 0.75^{\mathrm{a}, \mathrm{e}}$ \\
60 NP WOOD & $42.96 \pm 1.57^{\mathrm{b}, \mathrm{g}}$ & $6.26 \pm 1.30^{\mathrm{a}, \mathrm{g}}$ & $4.04 \pm 0.71^{\mathrm{a}, \mathrm{g}}$ \\
10 P WOOD & $63.23 \pm 3.76^{\mathrm{b}, \mathrm{a}}$ & $5.97 \pm 1.21^{\mathrm{a}, \mathrm{c}}$ & $3.96 \pm 1.16^{\mathrm{a}, \mathrm{c}}$ \\
30 P WOOD & $59.78 \pm 8.17^{\mathrm{b}, \mathrm{e}}$ & $4.68 \pm 1.23^{\mathrm{a}, \mathrm{e}}$ & $3.87 \pm 0.66^{\mathrm{a}, \mathrm{e}}$ \\
60 P WOOD & $65.37 \pm 7.54^{\mathrm{b}, \mathrm{g}}$ & $3.96 \pm 1.11^{\mathrm{a}, \mathrm{g}}$ & $3.40 \pm 0.78^{\mathrm{a}, \mathrm{g}}$ \\
\hline
\end{tabular}

Superscript $(a, b)$ compares control (group 1) with all the experimental groups. Superscript $(c, d)$ compares animals exposed to 10 minutes smoke generated from control wood with that from Test wood (group 2 and 5). Superscript (e,f) compares animal exposed to 30 minutes smoke generated from control wood with that from Test wood (group 3 and 6). Superscript (g,h) compares animals exposed to 60 minutes smoke generated from control wood with that from Test wood (group 4 and 7).Group with different superscripts are significant at $(\mathrm{p}<0.05)$.

Table 3: The Serum Level of Oxidative Stress Biomakers in Female Wistar Rat Exposed To Smoke Generated from Test Wood and Control Wood

\begin{tabular}{|c|c|c|c|c|}
\hline & SOD & $\mathrm{MDA}$ & CAT & GSH \\
\hline CONTROL & $20.39=1.14^{2}$ & $11.12 \pm 0.51^{\mathrm{s}}$ & $3.70 \pm 0.73 a$ & $0.33 \pm 0.04 a$ \\
\hline 10 NP WOOD & $26.56 \pm 1.53=\mathrm{c}$ & $12.31 \neq 0.79 \mathrm{ac}$ & $4.86 \pm 0.76 \mathrm{a}, \mathrm{c}$ & $0.39=0.06 a, c$ \\
\hline 30 NP WOOD & $33.56 \pm 1.61^{\text {the }}$ & $13.32 \pm 0.96^{2}=$ & $9.20 \pm 1.08 \mathrm{~b}, \mathrm{e}$ & $0.64 \pm 0.09 \mathrm{a}, \mathrm{e}$ \\
\hline $60 \mathrm{NP}$ WOOD & $33.89=1.77^{78}$ & $17.09=1.66^{28}$ & $13.92=0.94 \mathrm{~b}, \mathrm{~g}$ & $0.47 \pm 0.12 \mathrm{a}, \mathrm{g}$ \\
\hline 10 P WOOD & $27.81 \pm 3.01^{\mathrm{ac}}$ & $12.56 \pm 1.50^{\circ \mathrm{e}}$ & $3.76 \pm 0.67 \mathrm{a}, \mathrm{c}$ & $0.46 \pm 0.11 \mathrm{a}, \mathrm{c}$ \\
\hline $30 \mathrm{P}$ WOOD & $34.21 \pm 2.08^{\mathrm{kg}}$ & $24.93 \pm 2.63^{b z}$ & $6.32 \pm 1.45 \mathrm{a}, \mathrm{e}$ & $0.62 \pm 0.11 \mathrm{a}, \mathrm{e}$ \\
\hline 60 P WOOD & $36.30 \pm 4.66^{\mathrm{k}}=\mathrm{s}$ & $31.70 \pm 7.18^{\mathrm{bh}}$ & $24.56 \pm 2.13 b, h$ & $0.68 \pm 0.22 \mathrm{a}, \mathrm{g}$ \\
\hline
\end{tabular}

Superscript $(a, b)$ compares control (group 1) with all the experimental groups. Superscript $c, d$ compares animals exposed to 10 minutes smoke generated from wood harvested from non-crude oil polluted site and those harvested from crude oil polluted site (group 2 and 5). Superscript e,f compares animal exposed to 30 minutes smoke generated from wood harvested from non-crude oil polluted site and those harvested from crude oil polluted site (group 3 and 6). Superscript g,h compares animals exposed to 60 minutes smoke generated from wood harvested from non-crude oil polluted site and those harvested from crude oil polluted site (group 4 and 7). Group with different superscripts are significant at $(p<0.05)$.

The variations in oxidative stress biomarkers of female wistar rats exposed to smoke generated from the test wood at varying time shows that there was an increase in the level of all the oxidative stress biomarkers measured. In the case of SOD a significant increase $(\mathrm{p}<0.05)$ was observed in the animals exposed to smoke generated from wood collected from polluted environment for 30 minutes and 60 minutes when compared with the control and same was also noticed in animals exposed to smoke generated by control wood exposed for 30 and 60 minutes. There was also a significant increase $(\mathrm{p}<0.05)$ in MDA in animals exposed to 30 and 60 minutes of smoke generated by test wood when compared to the control. In the case of CAT, a significant increase $(\mathrm{p}<0.05)$ was observed in animals exposed to 30 and 60 minutes smoke generated from control wood and also in those exposed to 60 minutes smoke generated from test wood when compared to the control. Increments in GSH levels were not significant at $\mathrm{p}<0.05$.Elevated oxidative stress biomarkers in the serum only occur when there is more free radicals in the body than the body can handle. This is seen in some cases of disease condition or when free radicals are contributed by a foreign source (Cai and Harrison, 2000). Thesefree radical or oxidative stress poses a lot of health danger if not eradicated. They are the principal cause of aging, some class of cancer, premature menopausal symptoms, some auto immune diseases etc. The result of this study suggests that prolong smoke inhalation increases and prolongs oxidative stress. When they animals exposed to the same time duration but different wood were compared to each other a significant increase $(\mathrm{p}<0.05)$ was observed in MDA and CAT in group 7. This is an indication that the level of pollution in a wood affects the extent and intensity its smoke affect the oxidative biomarkers. Similar effect was seen by Steppanet al., (2001) and Salmon et al. (2010) who measured the effects of cigarette smoke on oxidative stress biomarkers of experimental animals. This revels that those that have no dream of smoking cigarette are faced with similar health effect when the inhale firewood smoke (Gilman and Zhou, 2004).

Conclusion: Woods have ability to absorb crude oil and when burnt, they are likely to produces more air pollutants. From the result of this study it was revealed that the pollutant in smoke generated from a wood collected from a crude oil polluted environment has not only increased amount of air pollutants but also has ability to increase oxidative stress and reduce female reproductive hormones in wistar rat faster than smoke generated from wood collected from a non-crude oil polluted environment suggesting a possible health danger to women that are frequently exposed to such woods.

\section{REFERENCES}

Benagiano, G; Brosens, I. (2006). History of adenomyosis. Best practice and research Clinical obstetrics and gynaecology, 20(4), 449-463.

Cai, H; Harrison, DG (2000). Endothelial dysfunction in cardiovascular diseases: the role of oxidant stress. Circulation Research, 87(10), 840-844. 
Caserta, D; Maranghi, L; Mantovani, A; Marci, R; Maranghi, F; Moscarini, M (2007). Impact of endocrine disruptor chemicals in gynaecology. Human reproduction update, 14(1), 59-72.

Clairborne, A (1995): Catalase activity In Greewald, A.R. ed. Handbook of methods for oxygen radical research. CRC Press. Boca Raton, FL. Pp 237-42.

Crisp, TM; Clegg, ED; Cooper, RL; Wood, WP; Anderson, DG; Baetcke, KP; Touart, LW (1998). Environmental endocrine disruption: an effects assessment and analysis. Environ. Health Perspect, 106(1), 11

De-Bruin, JP; Dorland, M; Spek, ER;Posthuma, G; Van-Haaften, M; Looman, CW (2002). Ultrastructure of the resting ovarian follicle pool in healthy young women.BiolReprod2002; 66: 1151-1160.

DeCherney, A; Marello, E; Hill, D; Munné, S (2003). Preimplantation genetic diagnosis as both a therapeutic and diagnostic tool in assisted reproductive technology. Fert.Steril. 80(2), 467468.

Foster, WG; Neal, MS; Han, MS; Dominguez, MM (2008). Environmental contaminants and human infertility: hypothesis or cause for concern $J$. Toxicol. Environ. Health, Part B, 11(3-4), 162176.

Gilman, SL; Zhou, X (Eds.) (2004). Smoke: a global history of smoking. Reaktion Books.

Gnoth, C; Godehardt, E; Frnk-Herrmann, P; Friol, K; Tigges, J; Freundl, G (2005).Definition and prevalence of subfertility and infertility. Hum. Reprod; 20(5):1144-7.

Linnane, AW; Kios, M; Vitetta, L (2007). Healthy aging: regulation of the metabolome by cellular redox modulation and prooxidantsignaling systems: the essential roles of superoxide anion and hydrogen peroxide. Biogerontology, 8(5), 445-467.

Mohallem, SV; De Araujo, DJ; Pesquero, CR; Assunção, JV; De Andre, PA., Saldiva, PH Dolhnikoff, M (2005). Decreased fertility in mice exposed to environmental air pollution in the city of Sao Paulo. Environ. Res, 98(2), 196-202.

Ohkawa, H; Ohishi, N; Yagi, K(1979) Assay for lipid peroxides in animal tissue by thiobarbituric acid reaction. Anal. Biochem. 95: 351-8

Salmon, AB; Richardson, A; Pérez, VI. (2010). Update on the oxidative stress theory of aging: does oxidative stress play a role in aging or healthy aging? Free Radic. Biol. Med, 48(5), 642655.

Sedlak, J; Lindsay, RH (1968).Estimation of total, protein-bound, and nonprotein sulfhydryl groups in tissue with Ellman's reagent. Anal. Biochem, 25, 192-205.

Steppan, CM; Bailey, ST; Bhat, S; Brown, EJ; Banerjee, RR; Wright, CM; Lazar, MA (2001). The hormone resisting links obesity to diabetes. Nature, 409(6818), 307-312.

Villeneuve, J; Palacios, JH; Savoie, P; Godbout, S (2012). A critical review of emission standards and regulations regarding biomass combustion in small scale units (< 3MW). Bioresour. Technol, 111, 1-11. 